\title{
ПОЛОЖЕНИЕ ЭСТОНИИ В ФИТОГЕОГРАФИЧЕСКИХ И ГЕОБОТАНИЧЕСКИХ РАСЧЛЕНЕНИЯХ СЕВЕРНОЙ ЕВРОПЫ
}

\author{
Л. Р. ЛААСИМЕР, \\ кандидат биологических наук
}

В основе классификации растительного покрова земного шара могут лежать два принципа: флористический состав, или состав флористических элементов (фитогеографическое расчленение), и распространение фнтоценологических единиц, как, например групп ассоциаций или формаций, типов и т. д. (геоботаническое расчленение). Результаты геоботанического районирования, особенно наиболее детального, касающегося ограниченных участков территории, часто используются на практике при планировании народного хозяйства. Часто, однако, применяют оба метода, т. е. при районировании на основе видового состава и элементов флоры учитывают наиболее распространенные типы вегетации и, наоборот, при геоботанических районированиях на основе учета растительных сообществ принимают во внимание и особенности распространения видов. Последний способ является наиболее оправданным, так как нельзя отделить распространение отдельных видов растеннй от обусловливающих это распространение факторов и так как в природных условиях виды растений не существуют вне соответствующих сообществ.

На относительно небольшой территорни Эстонии наблюдаются довольно большие различия в распространении как растительных сообществ, так и видов. В результате этого северная Эстония в известной степени отличается от южной, юго-восточная от северо-западной, западная от восточной и т. д. На основе этих различий проведено геоботаническое районирование. Учитывая флористические и - главное - геоботанические особенности, территорию Эстонии делят на две-геоботанические подпровинции, входящие в состав Прибалтийской геоботанической провинции. Геоботанические особенности связаны с геологическими, почвенными и климатическими условиями, что отмечено уже исследователями прошлого века, например Ф. Б. Шмидтом (Schmidt, 1858, 1865). Эти особенности определяются главным образом изменчивостью климатических или геоморфологических факторов, иногда же они обусловлены различными историческими процессами распространения отдельных характерных видов. На основании особенностей исторического развития мы отличаем, например, регионально различные сообщества переходных и верховых болот, а отчасти и низинных болот восточной и западной Эстонии, хотя экологические факторы этих сообществ почти во всем сходны. Таким образом, при геоботанической классификации, бесспорно, следует учитывать распространение и историю распространения встречающихся в составе сообществ видов. С другой стороны, нельзя объяснять все возникающие при фитогеографическом районировании особенности лишь с названных точек врения; следует учитывать и экологические условия и их изменения для того вида или сообщества, в составе которого он встречается или встречался ранее.

Далее мы анализируем положение территории Эстонин как части Прнбалтийской геоботанической провинции, подразделяя ее на крупные фитогеографичческие и типологические единицы. 
Согласно большинству классификаций или районирований растительного покрова земного шара, территорию Эстонии относят к зоне широколиственно-хвойных лесов северного умеренного пояса (или летнезеленых лесов, т. е. к подзоне елово-дубовых лесов без граба) отчасти же, при делении на крупные зоны лесной флоры, - к зоне хвойных лесов северного полушария, т. е. к зоне тайги (ср. Brockmann-Jerosch, Diels, Rübel, Hayek, Graebner, Алехин и др.). Эти подразделения, ставшие уже почти классическими, дают картину распространения наиболее крупных группировок типов растительности земного шара и их наиболее общих, обычно зависящих от климата, закономерностей. Такого рода классификации в отдельных своих частях недостаточно детальны и, следовательно, не могут помочь в решении поставленного здесь вопроса. Чтобы разрешить вопрос о положении Эстонии в фитогеографических и геоботанических (в первую очередь в геоботанических) системах Северной Европы, следует обратить внимание на те классификации, которые охватывают наиболее ограниченные части поверхности земного шара, в данном случае Северную или Восточную Европу, или же Прибалтику. Сюда относятся и классификации, определяющие положение южной границы зоны таежных хвойных лесов, особенно в западной ее части, так как по некоторым подразделениям Эстония помещается в подзоне южной тайги.

Упомянем в нескольких словах наиболее детальные районирования, а именно - классификации растительного покрова Эстонии.

Классификацией растительного покрова и флоры Әстонии занимались четыре автора. Первое районирование осуществил И. Гранэ (Granö, 1922), использовавший в качестве основы для своей карты районов основных и групповых форм обозначенные на топографических картах ландшафтные границы. В качестве единиц районирования были использованы занесенные на эти карты растительные формации или группы формаций: леса, верховые болота, болота, луга; при этом не давалось геоботанической и фитогеографической характеристики этих единиц, и поэтому даже не указано, являются ли леса рассматриваемой территории хвойными, смешанными или лиственными и т. д. Очевидно, что при решении вопроса о положении Эстонии с геоботанической точки зрения нельзя использовать классификацию Гранэ, хотя он и дает довольно детальный обзор расположения ландшафтных единиц на территории республики (рис. $1_{4}$ ).

Фитогеографическое деление Восточной Прибалтики, сделанное К. Купффером, было выполнено уже на основе распространения отдельных элементов флоры (Kupffer, 1925). При этом он иопользовал наблюдения и заметки Ф. Б. Шмидта (Schmidt, 1858, 1865) об особенностях растительного покрова силура и девона. Купффер считает всю Восточную Прибалтику одной флористичеокой областью (Bezirk) и делит ее на четыре подобласти (Unterbezirk), три из которых относятся к территории Эстонии. Эти три подобласти, в свою очередь, подразделяются им на 12 флористичеоких ландшафтов (Landschaft). На основе распространения горизонтов коренных пород Эстонии Купффер отделяет Subdistrictus siluricus и Subdistrictus devonicus (рис. $1_{2}$ ). Богатство островов Балтийского моря видами флоры и еe особенности в сравнении с флорой материка были причиной выделения самостоятельной области островов (Subdistrictus insularis). Основным критерием флористических особенностей материковой части Эстонии Купффер считает обилие извести в коренных породах силура в северной Әстонии, так как именно этим обусловливаются свойства почвы, от которых, в свою очередь, зависит богатство флоры данной местности. Ввиду того, что по классификации Купффера Эстонию пересекает маркантная граница между Subdistrictus siluricus и Subdistrictus devonicus, западную границу которой 
автор оставляет опкрытой, можно предположить, что он считает возможным ее продолжение в Швеции, в области соответствующих слоев, но не учитывает расположенной за Нарвой, в Ленинградской области, территории ордовика и проводит восточную границу этой области примерно вдоль реки Нарвы. Выводов о положении Эстонии в широком масштабе Купффер не делает.

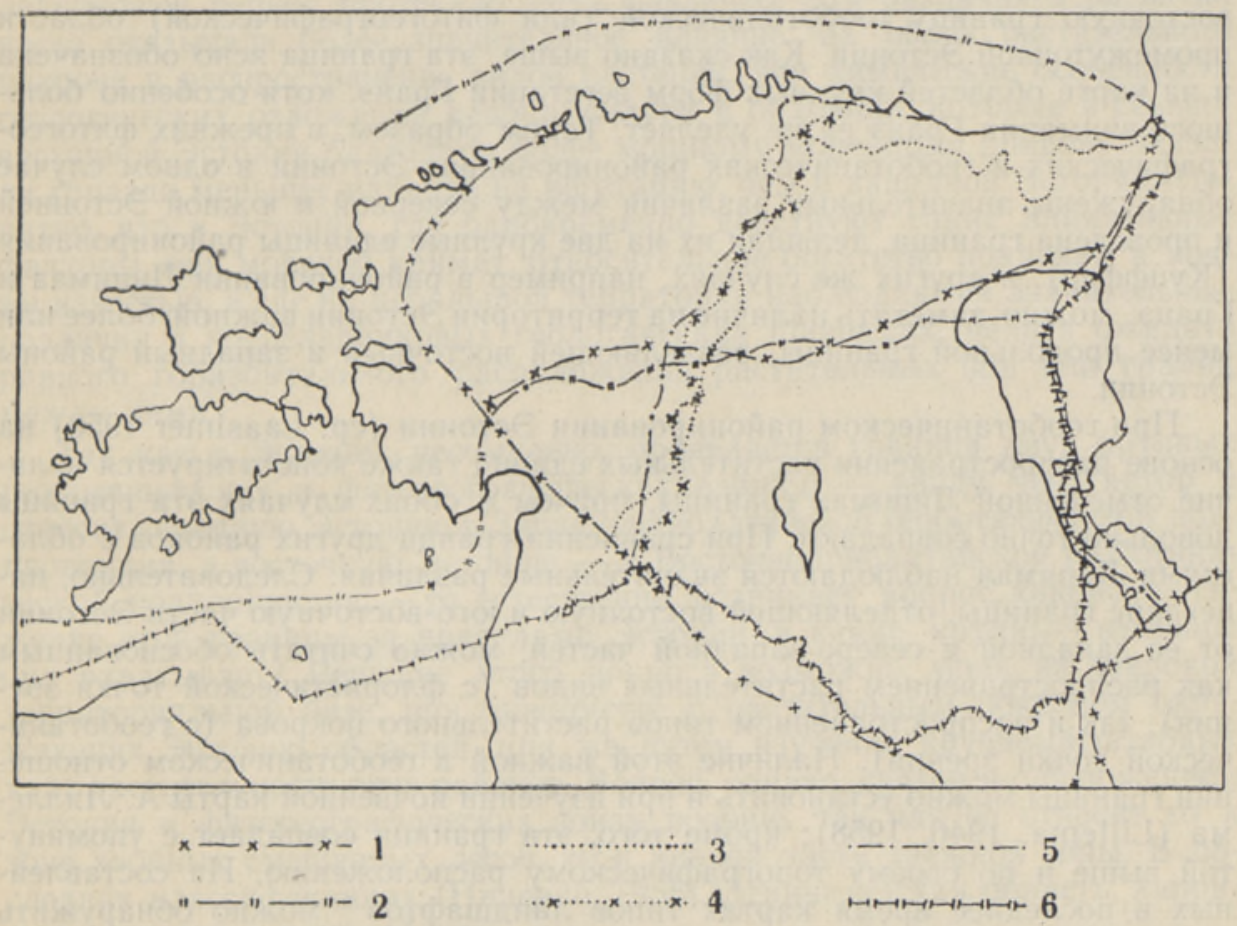

Рис. 1. Важнейшие гранищы существующих геоботанических и фитогеографических расчленений.

1 - границы округов по «Геоботаническому районированию СССР» (Игошина);

2 - границы между «Districtus siluricus» и «Districtus devonicus» по Купфферу;

3 - граница между западно-восточной и восточной геоботанической подпровинциями по Лаасимер; 4 - граница, установленная автором по карте крупных ландшафтных форм Гранэ; 5 - граница между фитогеографическими провинциями Средней и Восточной Европы по Липпмаа; 6 - граница республики.

Қак известно, Т. Липпмаа (Lippmaa, 1935) в своей геоботанической классификации Эстонии опирался на особенности распространения отдельных элементов флоры на ее территории (одновременно опираясь и на карту вегетащии крупных форм Гранэ). В наименованиях районов Липпмаа придерживается данных Купффером названий. Он также выделяет в Эстонии на основе коренных пород четыре округа, которые соответствуют округам Купффера (Bezirk); эти округа следующие: Districtus litoralis, D. siluricus, D. subsiluricus и D. devonicus (рис. $1_{5}$ ). Округа Липпмаа делит на области (по объему они соответствуют «ландшафтам» Купффера), которые он именует по географическим названиям ландшафтов. Следует, однако, отметить, что Липпмаа сильнее подчеркивает различия флоры восточной и западной частей Эстонии, чем южной и северной. Липпмаа придерживался той точки зрения, что принад- 
лежность Эстонии к двум фитогеографическим провинциям - западной и восточной - вполне обосновано [на основе геоботанической карты Европы Браун-Бланкэ (Braun-Blanquet, 1932)]. Липпмаа уточнил границу между ними и считал, что западная Әстония принадлежит к провинции Центральной Европы; централыную и восточную части Әстонии он относил к провинции Восточной Европы (или к Среднерусской). Упомянутая фитогеографическая граница проходит в направлении ют-юго-западсевер-северо-восток или, как считал Липпмаа, образует одновременно восточную границу геоботанической (или фитогеографической) области промежуточной Эстонии. Как сказано выше, эта праница ясно обозначена и на карте областей крупных форм вегетации Гранэ, хотя особенно большого внимания Гранэ ей не уделяет. Таким образом, в прежних фитогеографических и геоботанических районированиях Эстонии в одном случае обнаружены. значительные различия между северной и южной Эстонией и проведена граница, делящая их на две крупные единицы районирования (Купффер), в других же случаях, например в районировании Липпмаа и Гранэ, можно заметить наличие на территории Эстонии важной, более или менее продольной границы, разделяющей восточный и западный районы Эстонии.

При геоботаническом районировании Эстонии (ср. Laasimer 1958) на основе распространения растительных единиц также констатируется наличие отмеченной Липммаа границы, причем в обоих случаях эти границы довольно точно совпадают. При сравнении границ других районов с областями Липпмаа наблюдаются значительные различия. Следовательно, нанесение границы, отделяющей восточную и юго-восточную части Эстонии от ее западной и северо-западной частей, можно считать обоснованным как раопространением растительных видов (с флористической точки зрения), так и распространением типов растительного покрова (с геоботанической точки зрения). Наличие этой важной в геоботаническом отношении границы можно установить и при изучении почвенной карты А. Лиллема (Lillema, 1946, 1958); кроме того, эта граница совпадает с упомянутой выше и по своему топографическому расположению. На составленных в последнее время картах типов ландшафтов * можно обнаружить наличие такой границы также и в типах ландшафтов. Как по Липпмаа, так и по проведенному на основе карты растительнюсти геоботаническому районированию, эта граница образует бо́лышую часть восточной границы области промежуточной Эстонии (Lippmaa, 1935) или райюна верховых болот и болотистых лесов промежуточной Эстонии (Laasimer, 1958), проходящей по территории республики. Этот район благодаря своей удлиненной, узкой форме образует как бы переходную полосу между двумя геоботаническими подпровинциями.

Нельзя, конечно, требовать, чтобы границы используемых при районировании геологических, поовенных, ландшафтных или вегетационных единиц соответствовали друг другу на всем протяжении, так как при каждом специальном районировании ставится особая цель, которой соответствуют и исходные позиции и методы районирования. При различных районированиях на территории Эстонии важнейшие границы почвенных, географических, фитогеографических и геоботанических единиц проявляют тенденцию к совпадению, причем особенно ярко эта тенденция проявляется в отношении рассматриваемых здесь геоботанической и фитогеографической границ. Все это говорит о том, что деление западной и восточной Эстонии в геоботаническом и фитогеографическом отношении на две крупные единицы районирования достаточно обосновано. Эта граница более

* Составитель заведующий кафедрой географии ТГУ Э. Вареп (рукописи). 
или менее совпадает с границей максимального раопространения на нашей территории ледникового озера, на основании чего многие авторы отделяли так называемые «Низинную Эстонию» и «Возвышенную Эстонию». Эти две части значительно отличаются по своему рельефу, режиму влажности, моренному покрову и климатическим условиям. Низинная Эстония в течение продолжительного времени подвергалась влиянию ледниковых озер и позднейших трансгрессий, благодаря чему и развитие растительности в послеледниковый период протекало здесь различно. Эти различия в развитии часто оказывали более значительное влияние на облик растительного покрова и распространение видов растений, чем химические особенности геологических отложений девона, силура и ордовика, которые в северовосточной Эстонии благодаря более мощному моренному покрову оказали гораздо меньшее влияние на вегетацию, чем в западной Эстонии. Понятно, что в Эстонии, где одновременно действуют такие влиятельные факторы, как морской климат, относительное богатство подппочвы и почвы известью, и где на небольшой территории наблюдаются значительные различия в послеледниковых геологических процессах, нельзя ожидать равного горизонтального расположения растительных зон или границ между ними.

Так как в Әстонии, несомненно, проявляется граница двух крупных геоботанических и фитогеографических единиц - ввиду чего автор и относит западную Эстонию к Западноприбалтийской геоботанической подпровинции, а восточную Эстонию - к Восточноприбалтийской геоботанической подпровинции, - то естественно возникает вопрос, каково протяжение этой границы за пределами Эстонии и какие крупные единицы она охватывает? Решение этого вопроса возможно лишь на широкой территориальной базе, при знакомстве с растительным покровом окружающих Эстонию областей или же путем изучения крупномасштабных карт растительности этих районов. Вопрос, однако, связан и с положением Эстонии в фитогеографических зонах вообще, так как ее относят то к зоне хвойных смешанных лесов, то к южной части таежной зоны. В последних классификациях (Ниценко, 1958) Ленинградская область, например, отнесена к таежной зоне.

Детальные фитотеографические и геоботанические классификации Эстонии лишь вскользь касаются ее принадлежности к крупным единицам районирования, границы которых находятся далеко за пределами Әстонии. У Купффера охвачена и территория Латвии (так называемая Восточноприбалтийская область), но вопрос ю принадлежности Эстонии в широком смысле не ставится. Липпмаа рассматривает вопрос о данной фитогеографической границе несколько шире; он определяет принадлежность восточной и западной Эстонии в масштабах европейского районирования, но детальных высказываний на этот счет не делает.

На основе различных геоботанических, фитогеографических и геоморфологических класоификаций Әстонию (шире - все страны Прибалтики) относили то к Западной, то к Восточной, то к Центральной или Северной Европе. Понятие «Прибалтика» в разные времена имело различное значение. «Прибалтийский край» царскопо времени охватывал лишь современные Латвийскую и Эстонокую ССР. Немецкое название «Ostbaltikum» также означало Латвию и Эстонию. В старинной литературе Прибалтикой называли Әстонию, Латвию и Литву, главным образом потому, что они расположены на побережье Балтийского моря. Согласно трудам современных советских авторов, к Прибалтике, кроме Латвии, Эстонии и Литвы, относятся еще Калининградская и Ленинградская области, часть Белоруссии и Псковской области (см, изданные в 1947 г, «Геобота- 
ническое районирование СССР», «Геоморфологическое районирование СССР», «Естественно-историческое районирование СССР»).

Де Геер, однако, соединяет страны Прибалтики (главным образом Эстонию и Латвию) с Фенноскандией в одну большую географическую единицу «Балтоскандию» (De Geer, 1928). В подтверждение своей точки зрения он приводит 9 пунктов, из которых лишь первые четыре базируются на объективных природных признаках.

Понятие «Фенноскандия», включающее Скандинавию и Финляндию вместе с Кольским полуостровом и частью Карелии, является твердо обоснованным, созданным на базе геологического и геоморфологического строения и свойств. По коренным породам Фенноскандия относится к древней области складчатых гор, которые состоят из гранитных горных пород, подвергавшихся уже в пермский, карбонский и девонский периоды эрозии (денудации); восточнее, вне границ Фенноскандии, в те времена господствовало море, отложения которого образуют там более или менее ровную коренную породу. Поэтому ландшафт за пределами Фенноскандии более или менее ровный, с небольшим числом озер, широкими реками и т. д. Коренные породы Фенноскандии бедны известью, а за ее пределами они в изобилии ісодержат известь и т. д. Остается все же спорным вопрос о том, являются ли естественно-географические доводы Де Геера в пользу объединения Прибалтики с Фенноскандией в связи с полуостровным расположением вокруг Балтийскопо моря, границей распространения ледниковых форм и т. д. более значительными, чем те различия, которые можно констатировать в их коренных породах и почве. Нас интересует здесь, конечно, вопрос о пом, можно ли на основе сопоставления флоры и растительного покрова Прибалтики и Фенноскандии объединять их.

По А. К. Каяндеру (Cajander, 1900), восточная фитогеографическая граница Фенноскандии начинается от Белого моря, от устья реки Онеги, идет вдоль ее течения и вместе с образуемой ею дугой доходит до Онежского озера. Это и есть восточная граница стран, которые Норрлин (Norrlin, 1871) и Рамзай (Ramsay, 1898) уже в прошлом веке впервые назвали «Фенноскандией». А. Калела (Kalela, 1943) дает на основе фитогеографического материала характеристику этой восточной границы. Он устанавливает, что геологически обоснованная восточная граница Фенноскандии четко отражена и во флоре и в растительном покрове. Калела продолжает описанную его отцом, А. К. Каяндером, в 1900 г. восточную границу Фенноскандии от Онежского озера к Ладожскому, а оттуда далее до Финского залива, причем Карельский перешеек в фитогеографическом понимании также относит к Фенноскандии.

Эстонская ССР и страны Прибалтики по своим коренным породам резко отличаются от Фенноскандии. Но между Прибалтикой и южной частью Скандинавии; а также южной и, особенно, юпо-западной частью Финляндии имеются все-таки сходные черты в истории растительного покрова, в послеледниковой иммиграции видов и в распространении отдельных флористических элементов. Это сходство наблюдается главным образом в той части, которую А. Калела в своей недавно опубликованной карте зон лесной растительности Финляндии называет «островной Финляндией» («Saaristo-Suomi») и которая отнесена им к формации лиственных лесов Центральной Европы (Kalela, 1958). Особенно четко проявляется это сходство во флоре островов Балтийскопо моря (Сааремаа, Хийумаа, Эланд, Готланд) и во флоре материковой части западной Әстонии и южной части материка Скандинавии, а также во флоре побережья северной Эстонии, побережья южной и юго-западной Финляндии и Аландских островов. 
Оовобождение из-под ледника южной Скандинавии, особенно южной Швеции, происходило более или менее одновременно с северо-западной и западной Эстонией; следовательно, и послеледниковые этапы развития флоры и вегетации имеют некоторое сходство и совпадают по времени. Как показывает изучение послеледниковой иммиграции флористических элементов, особенно интенсивный обмен видами происходил между южной Скандинавией и западной Әстонией (т. е. западной частью Прибалтики). Известный процент растений восточного происхождения иммигрировал в южную Швецию главным образом через Прибалтику и Әстонию, причем основным овязующим звеном были здесь острова. С другой стороны, некоторые виды Западной и Южной Европы попали на территорию Эстонии через южную часть Скандинавии, причем многие из них на эстонском материке не перешагнули упоминавшейся выше фитогеографической границы между западной и восточной Эспонией (ср. Hultén, 1950). По составу флористических элементов западная и северо-западная Эстония имеют больше общего с южной Швецией, чем с восточной Эстонией. В геоботаническом отношении, при сравнении типов вегетации или растительных сообществ, также можно констатировать большое сходство между этими областями. Так, например, в западной Эстонии и в восточной части южной Швеции сходными типами растительности являются альвары, богатые по видовому составу лесолуга (шведские «löväng»), луга и широколиственнохвойные леса (Querceto-Piceetum); сходные растительные сообщества встречаются и на богатых видами низинных болотах (шведские «rikkärr»), в болотистых лесах и др.

Эти сходные черты в растителыном покрове обусловлены, с одной стороны, сходством современных экологических условий, а с другой - сходными условиями в прошлом, в течение всего послеледникового периода развития вегетации, как, например относительным обилием извести в почве и общими климатическими факторами. Не анализируя здесь климата южной Скандинавии, который, особенно в ее восточной части, сходен с климатом западной части Прибалтики, можно лишь упомянуть, что многие климатологи относят Әстонию к той же климатической области, что и южную Скандинавию. Некоторые климатологи проводили климатическую границу по территории Эстонии; так, Горчинский (Gorczynski, 1934) отделяет затадную Эстонию и большую часть западных районов Прибалтики от ее восточных районов и соединяет их с Центральной Европой и южной Шрецией в общую өбласть морсксто климата. Восточная граница этой области пересекает Эстонию приблизительно по линии Таллин-Валга. Восточная Эстония вместе с Финляндией, по мнению этого автора, относится к континентальной климатической области. Нелс (Nehls, 1933/34) также проводит климатическую границу по территории Эстонии, соединяя западную Эстонию, район Ленинграда, южную Финляндию и центральную часть южной Швеции (район больших юзер) в общую область с морским климатом. На территории Эстонии эта граница идет в направлении от Пярну к северному берегу Чудского озера. Восточные районы Прибалтики, по Нелсу, относятся к климатической области с возрастающей к востоку континентальностью. Другие, менее детальные климатические районирования, в которых на эстонокой территории не указывается никакой праницы, здесь не приводятся. Следует упомянуть, что и К. Кирде путем интерполяции на основании оредних продолжительно наблюдаемых температур воздуха определил средние широтные температуры и уклонения от этих средних и на этом основании (0-изаномалы) показал, что Әстония делится на две климатические области - западную и восточную (Kirde, 1943).

По климатическим условиям Эстония является переходным районом: 
морской климат переходит здесь в климат с непрерывно возрастающей континентальностью. Точно так же и в ее ботаническом и фитогеографическом облике можно констатировать переходные черты. В качестве переходной области с геопрафической точки зрения рассматривал Эстонию Халтенбергер (Haltenberger, 1925, 1926).

В фитогеографическом отношении можно констатировать, что в сравнении с южной Финляндией, Ленинградской областью и восточной Эстонией в западной Эстонии значительно выше процент европейских прибрежных растений, так же как и процент европейско-атлантического, субатлантического и североевропейского с бореомонтанной тенденцией флористических элементов (по Hultén'y, 1950). В восточной Эстонии, напротив, большую роль играют евразийский, североевропейский континентальный и восточносибирский континентальный флористические элементы.

Из числа классификаций растительного покрова Северной и Восточной Европы можно обратить внимание на некоторые новейшие, в которых Северная Европа рассмотрена нанболее детально, например, классификацию Цоллера (Zoller, 1956). Цоллер положил в основу деления флоры и растительного покрова Фенноскандии (так называемые «серии зон») границы распространения важнейших пород деревьев, чередование видов, характер типов лесов и комплексов верховых болот. Он помещает Прибалтику вместе с узкой полосой южной Финляндии и южной частью Скандинавии в область смешанных лесов. Эта зона, по Цоллеру, носит переходный характер, т. е. образует переходную ступень от так называемой бореомеридиональной серии зон к бореальной (по мнению автора, она все-таки ближе к бореальной серии зон). Прибалтийская подобласть, по Цоллеру, охватывает и центральную часть южной. Швеции, острова Балтийского моря и часть Прибалтики к северу от линии КлайпедаВильнюс. K сожалению, епо карта не отражает всей Прибалтики, но, повидимому, он не делает особого различия между ее западной и восточной частями Прибалтики.

Кнапп (Kпарр, 1948) относит Фенноскандию вместе с Прибалтикой к северосибирскому геоботаническому региону, причем делит территорию Эстонии на две зоны с помощью границы, идущей в направлении северюг (вернее, северо-запад - юго-восток). Он помешает узкую полосу загадной Эстонии и острова Балтийского моря вместе с южной Швецией и Данией, а также западной частью Латвии и почти всей Литвой и районом Калининграда в зону дубово-грабовых смешанных лесов. Восточную же Әстонию вместе с западной частью Ленниградской области, юго-западной Финляндией и северной частью южной Швеции (приблизительно к северу от больших озер) он относит к зоне перехода от еловых лесов к дубовограбовым смешанным лесам. Такая граница между восточной и западной Эстонией не обоснована, и нет причины относить западную Эстонию к зоне дубово-грабового смешанного леса, так как граб в настоящем климатическом периоде в природных растительных сообществах Әстонии вообще не встречіается.

Kраузе (Krause, 1952) в своем эскизе карты распространения важнейших растительных сообществ Европы и Западной Сибири проводит по территории Эстонии восточную границу смешанных широколиственнохвойных лесов (Querceto-Piceetum) Северной Европы; однако эта гріаница расположена значительно восточнее установленной эстонскими ботаниками фитогеографической или геоботанической границы. По мнению Краузе, восточная часть Эстонии относится к комплексу сообществ хвойных лесов Северной Европы (т. е. к зоне тайги!). Хотя эскиз карты Краузе носит лишь общий характер и не вполне соответствует действительности, 
здесь все же следует отметить то обстоятельство, что Краузе на своей карте показывает единство вегетации западной Эстонии с растительным покровом юго-западной Финляндии и южной Швеции и, наоборот, различие между западной и восточной Эстонией.

Шёрc (Sjörs, 1956) на своей карте флористической классификации Северной Европы также показывает общность восточной части южной Швеции и Прибалтики в широком смысле (т. е. включая Калининпрадскую, Ленинградскую и Псковскую области и т. д.); он относит их к провинции Центральной Европы и подпровинции Прибалтики. Шёрс считает также, что сюда относится узкая полоса южной и юго-западной Финляндии и лишь восточная часть Швеции, тогда как ее западная часть принадлежит к океанической подпровинции. На территории Эстонии он никакой границы не проводит. На карте областей вегетации Шёрса Прибалтика в широком смысле вместе с южной Швецией (шире - со всей южной Скандинавией) также относится к южной области хвойных лесов.

Из числа совепоких авторов основательное геоботаническое районирование принадлежит Игошиной («Геоботаническое районирование СССР», 1947). Она также проводит праницу между восточной и западной Эстонией, отделяя с помощью ее западную, так называемую полосу дубравнокустарниковых темнохвойных лесов, от восточной - полосы дубравнотравянистых темнохвойных лесов. Здесь идет речь о Восточноевропейской провинции Европейско-Сибирской подобласти темнохвойных лесов, которая относится к Евразийской хвойнолесной (таежной) области. К сожалению, карта не отражает расположенных за пределами Советского Союза районов или областей. Геоботаническая граница Игошиной на территории Әстонии не соответствует действительности по своему географичеокому и топографическому положению, а данная ею характеристика и наименования зон не соответствуют растительному покрову Эстонии (рис. $1_{1}$ ).

Что касается геоботанических районирований Скандинавии, то во всех них в общих чертах выделена в самостоятельную геоботаническую область центральная часть южной Швеции, начиная от южной границы северных хвойных лесов, расположенных к северу от больших озер, и до южной границы непрерывного распространения ели (Skåne). Эта центральная часть - так называемая область хвойно-широколиственных смешанных лесов - охватывает также узкую полосу юго-восточной Норвегии (ср. Добрынин, 1948, стр. 366, рис. 200).

Далее коснемся кратко вопроса принадлежности Эстонии к южной части зоны таежных хвойных лесов или к зоне хвойно-широколиственных смешанных лесов.

Вапрос состоит также в том, куда вообще относятся широколиственнохвойные леса (Querceto-Piceetum): к южной части таежной зоны или они составляют самостоятельную зону. И этот вопрос рассмотрен различными авторами по-разному. Если на карте геоботанических районов СССР территория Әстонии причисляется к области хвойных лесов (к тайге) Евразии, то на картах растительности СССР (1955 и 1956) зона широколиственно-хвойных смешанных лесов все-таки отделяется от лесов таежной зоны. По большинству действующих в настоящее время подразделений на зоны (или подзоны), Эстония относится к зоне хвойно-широколиственных лесов (см. Карту растительного покрова Европейской части СССР, 1:2 500 000, пояснительный текст, 1950, стр. 19; Растительный покров СССР, I, 1956, стр. 351; Алехин, 1950; Сочава, 1954; Курнаев, 1958 и др.).

Если ознакомиться с вопросами распространения ели, елово-смешанных и широколиственных лесов в Эстонии, ассоциациями еловых лесов и процессами происхождения их от широколиственных лесов, то выделение 
Прибалтики в зону хвойно-широколиственных лесов в общем вполне обосновано. Анализ изменений ассоциаций широколиственных лесов в ближайшем прошлом показывает, что теперешние беднейшие варианты ельников восточной Әстонии образовались в основном относительно недавно из богатых елово-широколиственных лесов в результате деятельности человека, вызывающей деградацию, а местами полное истребление лесных масоивов. Следовательно, Әстония должна быть целиком отнесена к зоне широколиственно-хвойных лесов. Возникает вопрос лишь о продолжении границы этой зоны за пределами Эстонии, в первую очередь в Ленинградокой области. На тех же упомянутых выше картах граница южной части таежной зоны и широколиственно-хвойных лесов пересекает Ленинградскую область. При этом расположенный за Нарвой район и плато ордовика Ленинградской области на этих картах относятся еще к зоне широколиственно-хвойных лесов, доходящей узкой полосой до Ленинграда, до восточной бухты Финокого залива.

В одной из свонх новейших работ А. Ниценко (1958), проводя границу между подзонами южной и центральной тайги и анализируя эту праницу в Ленинградской области, помешает западную часть Ленинградской области целиком в пределы южной тайги, которая граничит с восточной частью Эстонии. Возникает вопрос, как продолжить на территории Эстонии праницу подзоны южной тайги и зоны широколиственно-хвойных лесов (по Ниценко, границы подзон проходят восточнее границ Әстонии)? Единицей геоботанического районирования Эстонии, граничащей с Ленинградской областью, является «район верховых болот и болотистых лесов северовосточной Эстонии (Алутагузе)». В этом геоботаническом районе, чаще всего на карбонатных коренных породах, посподспвуют пески, травий и глины, составлявшие дно прежнего Чудского озера. Благодаря низменному рельефу процессы заболачивания протекают интенсивно. Преобладают различные болотистые и заболоченные леса и верховые болота. Из типов болотистых лесов встречается главным образом ассоциация Alnus glutinosa - Calla palustris, но также и ассоциация Alnus glutinosa Mercurialis perennis - Crepis paludosa. Последняя связана с более тонкими торфяными слоями и лучшими почвами. Часто в подлеске встречается и липа. Древесный ярус заболоченных лесов и лесов на переходных болотах обычно состоит из сосны и березы. Сухие и умеренновлажные лесные формации встречаются в этом районе лишь на узких и высоких гравийных озах, которые часто бывают богаты известью, в связи с чем на них и произрастают типичные широколиственно-хвойные леса; местами же, на расположенных между болотами песчаных и менее насыщенных известью грядах, распространены сухие сосновые леса, которые, несомненно, ранее были богаче по видовому составу, но уже с давних времен подвергаются влиянию человека (так как в прежние времена единственными путями передвижения среди заболоченного ландшафта были озы и гряды). По мнению автора данной работы, при делении растительного покрова на зоны в рассматриваемых областях следует учитывать главным образом леса на местообитаниях с наиболее благоприятными условиями произрастания, где климатические условия сказывают на характер вегетации максимальное влияние. Қак заболоченные, так и олиготрофные песчаные участки территории расположенных по-соседству зон, благодаря особенностям своего местообитания, могут иметь большое сходство (часто это экстразональные типы). В связи с этим не всегда можно решать вопрос c. принадлежности к зоне лишь на основе изучения заболачивающихся сосняков на болотистых песчаных почвах, верховых болот и сосновых лесов на песчаных почвах. Более существенными типами вегетации данного района при определении его принадлежности являются сухие и бога- 
тые по видовому составу леса, распространенные на озах или прядах, а отчасти и болотистые леса (последние имеют большое сходспво с болотистыми лесами геоботанического района верховых болот и болотистых лесов промежуточной Әстонии). Характер района, несомненно, промежуточный между южной частью таежной зоны и зоной широколиственнохвойных лесов; это так называемый переходный район, в котором смешались элементы флоры обеих зон. Поэтому проведение южной праницы подзоны южной тайги вдоль западной границы района верховых болот и болотистых лесов северо-восточной Эстонии столь же обосновано, как и проведение границы зоны широколиственно-хвойных лесов в Ленинградской области. Во всяком случае, плато ордовика Ленинградской области, совершенно сходное по облику растительного покрова с подрайоном возвышенности Пандивере в северной Эстонии ( ср. составленный Матвеевой макет карты растительности Ленинградской области), следует относить к зоне широколиственно-хвойных лесов, а приморский район Ленинградской области (Приморский район Курнаева), с геоботанической точки зрения, надо причислить к Западноприбалтийской подпровинции, тем самым и к зоне хвойно-широколиственных лесов. В основе такого деления лежат главным образом фитогеографические установки, так как в приморском районе Ленинградской области встречается столько же субатлантических и европейско-атлантических флористических элементов, растений европейского побережья, арктомонтанных европейско-континентальных и других флористических элементов, как и на северном морском побережье Эстонии и отчасти в западной Эстонии. Южная Финляндия и Аландские острова по тем же причинам относятся к геоботанической Западноприбалтийской подпровинции (одновременно к зоне широколиспвенно-хвойных лесов). Для Финляндии эту границу можно с наибольшей точностью провести на основе последнего районирования А. Калела (Kalela, 1958). Окончательное решение вопроса, относится ли зона широколиственно-хвойных лесов к таежной зоне или нет, не входит в задачу настоящей работы: Это необходимо решить путем тщательного сравнения лесных типов (или лесных ассоциаций). Основной целью рассмотрения указанного вопроса в данной статье является выяснение принадлежности Эстонии, а заодно и смежных областей, к высшего порядка единицам районирования, причем, конечно, нельзя было не остановиться на вопросе о растительных зонах, в пределах которых и проводятся геоботанические районирования.

Подводя итог приведенным соображениям различных авторов, следует констатировать, что многие из них относили район широколиственно-хвойных лесов южной Швеции к зоне вышеупомянутых широколиственно-хвойных лесов, охватывающих Прибалтику и продолжающихся в восточном направлении. С другой стороны, благодаря совпадениям изменчивости различных природных комплексов на территории Эстонии, показано, что здесь следует отделять две регионально отличные друг от друга по единицам растительного покрова и флоре области. Следователыно, выделение двух крупных единиц районирования здесь полностью обосновано (Lippmaa, 1935; Laasimer, 1958). Если родственные черты для восточной геоботанической единицы районирования следует искать в находящихся за пределами Эстонии восточных областях, то западная крупная геоботаническая единица имеет большое число сходных черт с южной частью Скандинавии или Фенноскандии. Некоторое сходство наблюдается и в растительном покрове узкой западной приморской полосы Латвии и Литвы; отсюда мы заключаем, что западная часть Прибалтики, а особенно западная и северо-западная части Эстонии вместе с островами Балтийского моря должны быть отнесены к общей и для 
южной части Фенноскандии высшей единице геоботанического и фитогеографического районирования, независимо от того, как она будет названа (округом, провинцией или подпровинцией - это зависит от степени детальности единиц районирования). Автор придерживается той точки зрения, что западная Әстония представляет собой единицу геоботанического районирования, ж которой относятся восточная часть южной Скандинавии и острова Эланд и Готланд. Эту область автор в овоей схеме

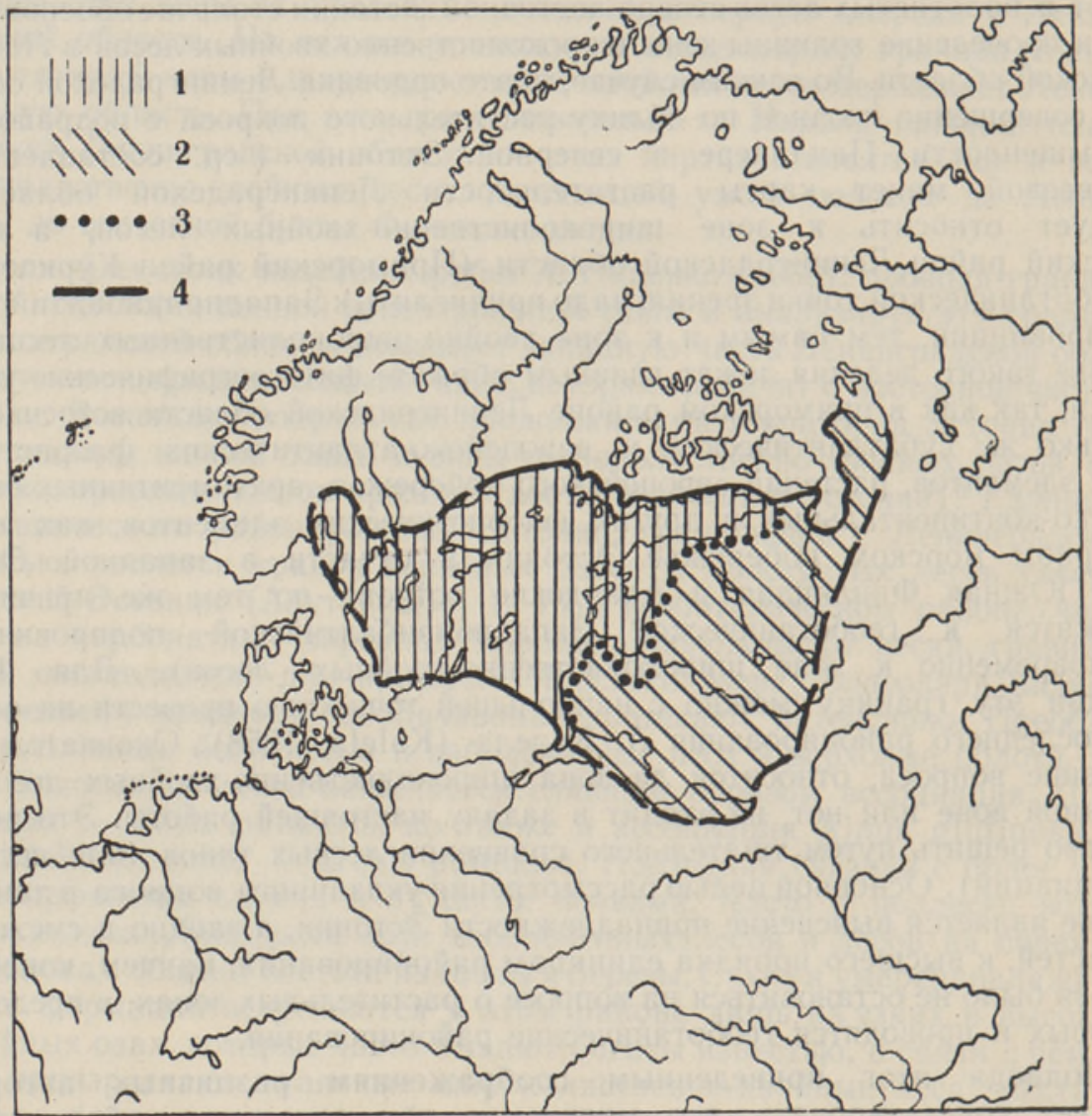

Рис. 2. Границы Прибалтийской геоботанической провинции.

1 - западная подпровинция; 2 - восточная подпровинция; 3 - граница между подпровинциями; 4 - границы, требующие дальнейшего уточнения.

геоботанического районирования назвал Западноприбалтийской геоботанической подпровинцией. На севере сюда относится и часть южной Финляндии, главным образом юго-западная часть ее вместе с Аландскими островами. Восточная же Эстония отличается от этой геоботанической подпровинции как с фитогеографической, так и геоботанической почек зрения; она имеет сходные черты с расположенными к востоку от Эстонии западными областями РСФСР, особенно іс Поковской областью, и образует другую геоботаническую подпровинцию, куда относится область к востоку от Чудского озера, приблизительно до линии, которую можно провести вдоль реки Волхов к озеру Ильмень, Великим Лукам, Витебску, Вильнюсу и Клайпеде (рис. 2). Эту геоботаническую единицу, в которую 
входит восточная Эстония, автор относит к Восточноприбалтийской геоботанической подпровинции.

Если считать главным признаком для отделения Фенноскандии коренные породы, основную морену и почву (бедную известью), рельеф и т. п., то территорию Эстонии или Прибалтики нельзя относить к Фенноскандии; также не подходит наименование «Балтоскандия» в смысле Де Геера. Однако, на основании тех же различий в геологических, почвенных и геоморфологических условиях нельзя было бы отнести $\ltimes$ Фенноскандии и южную Скандинавию, так как геолого-географические условия области широколиственно-хвойных лесов южной Скандинавии не имеют характерных для остальной территории Фенноскандии черт. С геологической точки зрения, К Фенноскандии не относится самая южная часть Скандинавии - Сконе. По своему растительному покрову и флоре южная Скандинавия родственна Прибалтике - особенно западной ее части.

Поскольку на Аландских островах и на материковой части юго-западной Финляндии встречаются одни и те же элементы флоры и растительные сообщества (распространение лиственных пород и ельников с широколиственными элементами, Taxus baccata и других более западных видов; отсутствуют только альвары), то вполне обосновано включение этих областей в Западноприбалтийскую геоботаническую подпровинцию, хотя по коренным породам и почвенным условиям они отличаются от других составных частей этой подпровинции.

Причины сходства вегетации юго-западной Финляндии, южной Швеции и западной Эстонии кроются не только в общности климатических и почвенных условий этих областей, но и в общности развития растительного покрова на протяжении послеледникового периода, в почти одновременной иммиграции видов растений после отступания ледниковых озер, Анцилового озера и Литоринового моря. Учитывая характер вегетации, единство ее развития и сходство экологических условий, следовало бы объединить с Западноприбалтийской геоботанической подпровинцией следующие районы: узкую полосу северното побережья Эстонии, южное побережье Финского залива от Нарвы до Ленинграда (плато ордовика!) и побережье Финскопо залива, узкую полосу западного побережья Латвии и часть западного побережья Литвы.

Восточная граница геоботанической подпровинции Восточной Прибалтики нуждается в уточнении путем внимательного сравнения границ распространения растительных сообществ и видов. Северная, южная и западная границы геоботанической провинции Прибалтики более или менее точно совпадают с границами распространения ассоциации Picea excelsa - Galeobdolon - Asperula - Eurhynchium striatum и одновременно с границей ассоциации Ulmus - Tilia - Galeobdolon - Asperula и границей субассоциации Quercus robur или, иными словами, на севеpe - c траницей непрерывного раопространения дуба, на западе и юге с южной границей непрерывного распространения Picea excelsa; восточная граница еще не вполне точно установлена. По мнению автора данной работы, эта граница могла бы приблизительно совпадать с линией озеро Ильмень - Великие Луки - Витебск, которая более или менее соответствует границе Прибалтийской провинции по естественно-историческому районированию Советскопо Союза (1947). Она в общих чертах совпала бы также по схеме геоморфологического районирования Советского Союза («Геоморфологическое районирование СССР», 1947) с первой областью северо-западного денудационного плато ледникового рельефа. Южные границы Восточноприбалтийской подпровинции, а также всей Прибалтийской провинции, в которую входят обе рассматриваемые подпровинции, в общих чертах совпадают с южной границей распространения 
широколиственно-хвойных лесов (Querceto-Piceetum), а также с южной границей главной северной области распространения ели.

Прибалтийская геоботаническая провинция охватывает, таким образом, всю западную часть северного района зоны широколиственно-хвойных лесов. Вопрос о точных границах Прибалтийской геоботанической провинции может быть решен путем сравнения соответствующих карт растительного покрова и с помощью дополнительных исследований распространения отделыных элементов флоры и фитоценотических единиц (взятых в соответствующем объеме, т. е. по возможности выполненных одним исследователем или исследователем той же школы). Упоминавшиеся здесь границы (рис. 2) пока являются лишь схемой; вполне уточнена лишь граница, проходящая по территории Эстонской ССР.

В заключение встает вопрос, как рассматривать фитогеографическое и геоботаническое приобщение Прибалтики к Фенноскандии? Продолжается ли граница Фенноскандии на юг от Финского залива, а если продолжается, то как? По Калела (Kalela, 1943) и Хиндонену (Hiitonen, 1946), четкая фитогеографическая траница Фенноскандии огибает плато ордовика с северной стороны, почти совпадая с прежней границей Ингерманландии и достигая Финского залива. По установкам этих исследователей, относить Эстонию к Фенноскандии нельзя (богатые известью почвы и обилие кальцефильных растений в противоположность существующим в Фенноскандии условиям и т. д.).

В скандинавской литературе мы не встречаем специальных указаний о том, тянется ли южная или юго-восточная граница Фенноскандии вдоль Финского залива; вопрос об этой южной границе вообще мало разработан. Если придерживаться классически сформировавшегося понятия «Фенноскандии» и учитывать при этом точки зрения Каяндера, Калела, Хиидонена и Лютера (Luther, 1954) на фитогеографическую Фенноскандию, то южная Швеция (особенно ее восточная часть) останется за ее пределами. Так поступает Шёрс (Sjörs, 1956) при отделении фитогеографических провинций Северной Европы. Он относиткпровинции Фенноскандии, с учетом ботанических особенностей, только северную Швецию и Финляндию (за исключением небольшой части ее юго-западного и южного пюбережья); восточная часть южной Швеции (а также юго-западное побережье Финляндии) принадлежит к Прибалтийской провинции. Таким образом, по Шёрсу фитогеографическая Фенноскандия значительно меньше геологической. Следовательно, Эстония, т. е. Прибалтийская геоботаническая провинция, по делению Шёрса, не входит в п̆онятие Фенноскандии. Если расширить это понятие до понятия «Балтоскандия», то эти области можно соединить, но это, несомненно, не обосновано ни с геоботанической, ни с фитогеографической точки зрения, так как большая часть геологической Фенноскандии целиком относится к таежной зоне.

Намеченную на карте районирования Северной Европы Шёрса западную и южную границу Прибалтийской подпровинции следует принять за основу границы Прибалтийской провинции в понимании автора данной работы. Восточная же часть границы упомянутой подпровинции Шёрсом совсем не разработана, точно так же на этой карте отсутствует детальное внутреннее деление провинции на восток от Балтийского моря.

Прибалтийская геоботаническая провинция является самостоятельной единицей, и ее следует отделять от провинций Центральной и Восточной Европы. Прибалтийская геоботаническая провинция включает западную часть зоны широколиственно-хвойных лесов и как в геоботаническом, так и в флористичеоком отнощении является связующим звеном (буферной областью) между зоной широколиственных лесов Центральной и Южной Европы и зоной хвойных таежных лесов; в западно-восточном направ- 
лении она представляет собой связующее звено между приспособившейся к условиям атлантического климата растительностью и растительностью восточных континентальных областей. Внутри провинции зафиксировано наличие границы, где переход между западным, с одной стороны, и восточным, с другой стороны, влияниями проявляется сравнительно маркантно; это обусловлено как развитием вегетации рассматриваемой области в послеледниковом периоде, так и климатическими и почвенными условиями. Эта переходная территория обозначает собою границу двух Прибалтийоких подпровинций - Восточной и Западной. В дальнейших иоследованиях следует уточнить границу Восточной Прибалтийской подпровинции.

\section{Л ИТЕ РА Т У РА}

Ал е х и н В. В., 1950. География растений. М.

Ал е хин В. В., 1951. Растительность СССР. М.

Геоботаническая карта СССР. М. 1:4000 000, 1956. Под ред. Е. М. Лавренко и В. Б. Сочавы. М.-Л.

Геоботаническое районирование СССР, 1947. Под. ред. Е. М. Лавренко. М.-Л.

Геоморфологическое районирование СССР, 1947. Под ред. К. К. Маркова. М.-Л.

Д о 6 р ын и н Б. Ф., 1948. Физическая география Западной Европы. Москва.

Естественно-историческое районирование СССР, 1947. Под ред. Д. Г. Виленского. М.-Л.

Карта растительности Европейской части СССР. М. 1:2500000, 1948. Под ред. Е. М. Лавренко и В. Б. Сочавы. Л.

K у н а е в С. Ф., 1958. Лесорастительное районирование подзоны южной тайги и хвойно-широколиственных лесов Европейской части СССР. Инст. леса $\mathrm{AH}$ CCCP. M.

Л а а с и ме р Л. Р., 1958. Геоботаническое районирование Эстонской ССР. Ботаническии журнал, XLIII, 3.

Н и це н ко А. А., 1958. К вопросу о границе среднетаежной и южнотаежной подзоны в пределах Ленинградской области. Ботанический журнал, XLIII, 5.

Растительный покров СССР I, 1956. Пояснительный текст к «Геоботанической карте $\mathrm{CCCP}$.

С о ч а в а В. Б., 1954. Геоботаническая карта СССР. Природа, № 10.

Br a un-B 1 a nquet, J., 1932. Plant Sociology. New York-London.

C a j a nder, A. K., 1900. Fenno-Scandian kasvitieteellisestä kaakkoisrajasta. Meddel. Soc. F. Fl. Fenn., 26.

De Geer, S., 1928. Das geologische Fennoskandia und das geographische Baltoskandia. Geogr. Annalen, 1.

G or czyns Ki, W., 1934. Decimal Scheme of World's Climates with Adaption to Europe.

Gr a n ö, I. G., 1922. Eesti maastikulised üksused. Loodus, 1, 2-5.

$\mathrm{H}$ al t en ber ger, M., 1925. Gehört das Baltikum zu Ost-, Nord- oder zu Mitteleuropa? Publ. Inst. Geogr. Univ. Dorpatensis, 1.

$\mathrm{H}$ a 1 t en berger, M., 1926. Landeskunde von Eesti. Publ. Inst. Geogr. Univ. Dorpatensis, $6-10$.

Hi iton en, I., 1946. Karjalan kannas kasvien vaellustienä lajien nykylevinneisyyden valossa. Ref.: Die Karelische Landenge als Einwanderungsweg der Pflanzenarten im Lichte ihrer heutigen Verbreıtung. Ann. Bot. Soc, Zool. Bot. Fenn. «Vanamo», 22, 1.

Hultén, E., 1950. Atlas över växternas utbredning i Norden. Stockholm.

$\mathrm{K}$ a le la, A, 1943. Die Ostgrenze Fennoskandiens in pflanzengeographischer Beziehung. Veröff. d. Geobot. Inst. Rübel in Zürich, 20.

K a le l a, A., 1958. Suomen metsäkasvillisuusvyöhykkeet ja Ragnar Hult. Ref. Die Waldvegetationszonen Finnlands und Ragnar Hult. Terra, 1.

Kir de, K., 1943. Kliima-valdkonnad Eestis. Acta et Comment. Univ. Tartuensis, A-XXXVIII.

Kn a p p, R., 1948. Einführung in die Pflanzensoziologie. Stuttgart.

Kra us e, W., 1952. Das Mosaik der Pflanzengesellschaften und seine Bedeutung für die Vegetationskunde. Planta, 41.

Kupffer, K. R., 1925. Grundzüge der Pflanzengeographie des Ostbaltischen Gebietes. Abh. Herder-Inst. zu Riga, 1, 6. 
L a a s imer, L., 1958. Eesti NSV geobotaaniline rajoneerimine. Tartu.

Li 11 e m a, A., 1946. Lühike mullaerimite kirjeldus Eesti NSV mullastiku kaardi juurde. Tallinn.

Li 11 e m a, A., 1958. Eesti NSV mullastik. Tallinn.

L i p p m a a, T., 1935. Eesti geobotaanika pōhijooni, Acta et Comment. Univ. Tartuensis, A-XXVIII, 4.

L u ther, H., 1954. Fennoskandiens gräns i Vita havet. Memor. Soc. pro Fauna et Fl. Fenn., 29.

Nehls, E., 1933/34. Das Klima des Ostseegebietes, 51/52. Jahrbuch der Pommerschen geographischen Gesellschaft, Sitz Greifswald.

Norrlin, J. P., 1871. Flora Kareliae Onegensis. I. Notiser Sällsk. F. Fl. Fenn. Förh., 13.

R a ms a y, W., 1898. Ober die geologische Entwicklung der Halbinsel Kola in der Quartärzeit. I. Fennia 16.

$\mathrm{S} \mathrm{chmidt,} \mathrm{F.} \mathrm{B.,} \mathrm{1858.} \mathrm{Untersuchungen} \mathrm{über} \mathrm{die} \mathrm{silurische} \mathrm{Formation} \mathrm{in} \mathrm{Estland,}$ Nord-Livland und Osel. Arch. f. die Naturk. Liv-, Ehst- und Kurlands, 1. Ser., II.

Schmidt, F. B., 1865. Flora des silurischen Bodens von Ehstland, Nord-Livland u. Oesel. Arch. f, die Naturk. Liv-, Ehst- und Kurlands, 2. Ser., I.

S jörs, H., 1956. Nordisk växtgeografi. Stockholm.

Zolle r, H., 1956. Die natürliche Grossgliederung der Fennoskandischen Vegetation und Flora. Ber. ü. d. Geobot. Forsch. Inst. Rübel in Zürich f. d. Jahr 1955.

Ннститут зоологии и ботаники

Академии наук Эстонской ССР
Поступила в редакцию

5 II 1959

\title{
EESTI ASETUS PÕHJA-EUROOPA TAIMEGEOGRAAFILISTES
} JA GEOBOTAANILISTES LIIGESTUSTES

\author{
L. Laasimer,. \\ bioloogiateaduste kandidaat
}

Resümee

Eesti NSV territooriumi pōhja-, loode- ia lääneosa erinevad oma floora ja vegetatsiooni poolest Lõuna-, Kagu-, Kesk- ja Ida-Eestist. Seda erinevust on konstateerinud uurijad juba möödunud sajandil, kes seostasid seda fakti peamiselt geoloogilise aluspōhja iseärasustega, tehes vahet Põhja- ja Lõuna-Eesti floora ning ivegetatsiooni vahel.

oksikute flooraelementide leviku iseärasuste detailsemal uurimisel Eesti territooriumil jōudis T. Lippmaa järeldusele, et Lääne- ja Loode-Eesti taimegeograafiliselt Kirde-, Ida- ja Kagu-Eestist tunduvalt rohkem erinevad kui Pōhja-Eesti Lōuna-Eestist. T. Lippmaa liigitas Lääne-Eesti Kesk-Euroopa taimegeograafilisse provintsi, Kesk- ja Ida-Eesti paigutas ta aga Ida-Euroopa (resp. Kesk-Vene) provintsi. T. Lippmaa detailiseeris nende provintside vahelise piiri Eesti territooriumil.

Eesti NSV taimkatte kaardi alusel on autor teostanud Eesti NSV geobotaanilise rajoneerimise. Taimekoosluste iseärasuste ja nende leviku analüüsimisel ilmnes, et Lääne- ning Loode- ja Ida- ning Kagu-Eesti vahel on olemas niivōrd ulatuslikud lahkuminekud, mis teevad vajalikuks rajoneerida nad kahte erinevasse kõrgemasse ühikusse. Piir nende vahel sobib hästi T. Lippmaa poolt pōhjendatud taimegeograafilise piiriga.

Nimetatud piiri tingivad mitmesugused tegurid, millest tähtsamad on erinevused lääne- ja idapoolse Eesti taimkatte postglatsiaalses arengus, samuti reljeefis, veerežiimis, moreenkattes, mullastikus ja klimaatilistes tingimustes.

Autor on selle piiriga teineteisest eraldatud ühikud nimetanud Baltikumi geobotaanilise provintsi Lääne- ja Ida-Baltikumi alamprovintsiks. Analüüsides nende alamprovintside jätkumist väljaspool Eesti NSV-d ja vōrreldes Eesti NSV asukohta mitmete autorite taimegeograafilistes ja geobotaanilisies liigestustes, jōuab käesoleva autor järgmistele seisukohtadele:

1. Eesti paigutub laialehiste okas- ja segametsade taimestikuvöötme pōhjapoolsesse ossa; lōuna-taiga metsade löunapiir ei ulatu Eesti NSV administratiivsete piirideni, kui 
mitte lugeda üldse laialehiste okas- ja segametsade taimestikuvöötme kuulumist taigametsade lōunaosa juurde (kuigi edaafiliselt tingitud sarnaseid jooni leidub Ida-Baltikumi alamprovintsis, nimelt Kirde-Eesti ja Leningradi oblasti mõningates metsatüüpides).

2. Arvestades Eesti (eriti Lääne-Eesti) taimekoosluste sarnasust Lõuna-Rootsi idaosaga, tuleks neid territooriume lugeda ühte ja samasse suuremasse geobotaanilisse ühikusse, mida autor on nimetanud Baltikumi provintsiks. Selles provintsis tuleb eraldada kaks suuremat alamühikut (Lääne- ja Ida-Baltikumi alamprovints), millevaheline piir läbib Eesti NSV territooriumi NNE-SSW suunas ning jätkub väljaspool Eesti NSV piire.

3. Baltikumi geobotaaniline provints ei kuulu ei Ida- ega Kesk-Euroopa juurde, ka mitte Fennoskandia juurde. Floora ja vegetatsiooni iseloomu poolest moodustab ta üleminekuala nende territooriumide vahel. Siinjuures on Lääne-Baltikumi alamprovintsil teatavaid ühisjooni Kesk-Euroopa provintsiga, Ida-Baltikumi alamprovintsil Ida-Euroopa provintsiga.

Baltikumi provintsi piirid väljaspool Eesti NSV-d vajavad fikseerimist võimalikult detailselt rekonstrueeritud taimkattekaartide alusel, näit. samalaadselt nagu selle provintsi kahe alamprovintsi vahelise piiri määramine Eesti NSV piires. Sellise töö eelduseks on kahtlemata vajalik laialdasemate Pōhja-Euroopa alade taimkatte kaardistamine suuremas kaardimõõdus.

Eesti NSV Teaduste Akadeemia Zooloogia ja Botaanika Instituut

Saabus toimetusse

5. II 1959

\section{THE POSITION OF ESTONIA IN PHYTOGEOGRAPHICAL AND GEOBOTANICAL PARTITIONS OF NORTH EUROPE}

\section{Laasimer}

\section{Summary}

The flora and vegetation of the North, Northwest and West of the territory of the Estonian S.S.R. differ from those of the South, Southeast and East.

This difference was already noticed by research workers of the past century, who attributed it mainly to peculiarities of the subsoil and drew a line of demarcation between the flora and vegetations of North and South Estonia.

T. Lippmaa, studying in detail the distribution of certain floristic elements on Estonian territory, arrived at the conclusion that the difference between West and Northwest Estonia and the east, northeast and southeast sections of the republic was, from the phytogeographical point of view, far greater than the difference between North and South Estonia. Lippmaa added West Estonia to the phytogeographical province of Central Europe, and East Estonia to that of East Europe (i. e. Central Russia). He also gave a detailed description of the borderline between these two regions in Estonia.

On the basis of a geobotanical map of Estonia the author constructed a geobotanical partition of the Estonian S.S.R. The differences in structure and distribution of the plant communities between West and Northwest Estonia on the one hand and East and Southeast Estonia on the other hand, are so striking that it is necessary to group them in different higher units of a geobotanical division. The boundary between these two higher units accords well with the line of demarcation separating the two phytogeographical provinces established by Lippmaa.

The formation of such a vegetation boundary between East and West :Estonia may be explained by various factors, the most important of which are the differences in relief, moraine layer, soil, water regime, climatic conditions and the postglacial development of the flora and vegetation.

The author names the two regions divided by this boundary as the East and West subprovinces of the Baltic geobotanical province.

Analysing the continuation of the borders of these subprovinces outside Estonian territory and comparing the position of Estonia in the phytogeographical and geobotanical schemes of various authors, the author of the present paper comes to the following conclusions. 
Estonia belongs geobotanically to the northern part of the coniferous and broadleafed deciduous mixed forest zone; the south frontier of the southern-taiga forests does not reach the territory of the Estonian S.S.R. (although some edaphically determined features are found in North-East Estonian forest types of the East Baltic subprovince).

Taking into account the affinity between the plant communities of Estonia (especially West Estonia) and South Sweden, it is expedient to group these territories into the same larger unit of a geobotanical division, which we here call the Baltic geobotanical province. The Baltic geobotanical province is divided into two larger subunits (West Baltic and East Baltic subprovinces), the boundary between which crosses the territory of the Estonian S.S.R. diagonally in the direction NNE to SSW and continues beyond the frontiers of the republic.

The Baltic province does not belong geobotanically either to East or to Central Europe; but neither does it belong to Fennoscandia. In the character of its flora and vegetation the Baltic province occupies a transitional position between the abovementioned geographical regions. Nevertheless, the West Baltic subprovince possesses certain features in common with the phytogeographical province of Central Europe, and the East Baltic subprovince with that of East Europe (i. e. Central Russia).

The further boundaries of the Baltic province outside the Estonian S.S.R. should be determined with the help of detailed reconstructed geobotanical maps, in the same way as the borderline between the two subprovinces was determined on Estonian territory. An essential pre-requisite to the fulfilment of this task is unquestionably the preparation of large-scale geobotanical maps of North Europe.

Academy of Sciences of the Estonian S.S.R., Institute of Zoology and Botany

Received

Febr. 5th, 1959 